\title{
Polyphasic evaluation of Limnoraphis robusta, a water-bloom forming cyanobacterium from Lake Atitlán, Guatemala, with a description of Limnoraphis gen. nov.
}

\author{
Jiří KOMÁREK ${ }^{1 *}$, Eliška ZAPOMĚLovÁ ${ }^{2}$ Jan ŠMARDA ${ }^{3}$, Jiří KOPECKÝ ${ }^{4}$, Eliška \\ REJMÁNKovÁ ${ }^{5}$, Jason WoodHouse ${ }^{6}$, Brett A. NeILAN ${ }^{6} \&$ Jaroslava KomÁRKovÁ $^{2}$
}

\author{
${ }^{1}$ Institute of Botany AS CR and University of South Bohemia, Dukelská 135, CZ - 37982 Třebon̆, Czech \\ Republic \\ ${ }^{2}$ Biology Centre of AS CR, Institute of Hydrobiology, Na Sádkách 7, CZ 37005 České Budějovice, Czech \\ Republic \\ ${ }^{3}$ Department of Biology, Faculty of Medicine, Masaryk University, Kamenice 5, CZ- 62500 Brno - Bohunice, \\ Czech Republic \\ ${ }^{4}$ Institute of Microbiology AS CR, Opatovický mlýn, CZ-379 81 Třebon̆, Czech Republic \\ ${ }^{5}$ University of California, Davis, One Shields Ave., Davis, CA 95616, USA \\ ${ }^{6}$ Centre for Cyanobacteria and Astrobiology, University of New South Wales, Sydney, NSW 2052, Australia
}

\begin{abstract}
A tropical planktic filamentous cyanobacterium, tentatively identified as Lyngbya robusta, recently increased in abundance in Lake Atitlán, Guatemala, and since 2008 annual water-blooms occurred. This was one from the first known cases of $L$. robusta water-blooms worldwide. A polyphasic evaluation of $L$. robusta using $16 \mathrm{~S}$ rRNA gene sequencing, cytomorphological markers, and ecological characteristics was made. This species had several unique features. It produced aerotopes that were irregularly spaced in cells; cyanotoxins were not found, and it fixed nitrogen in spite of the lack of heterocytes. It contained a high amount of carotenoids, which caused an unusual brown color of the macroscopic scum on the water level. Molecular phylogenetic analyses using the $16 \mathrm{~S}$ rRNA gene showed that $L$. robusta, together with few other planktic species, formed a clade, separated from typical Lyngbya species. The main diacritical markers of this clade were the planktic type of life and formation of gas vesicles in cells. Based upon molecular, morphological and ecological data, a new genus Limnoraphis was proposed with four species.
\end{abstract}

Key words: carotenoids, ecology, Guatemala, Lake Atitlán, Limnoraphis, planktic Lyngbya, taxonomy, ultrastructure, water-blooms

\section{Introduction}

Planktic, water-bloom forming cyanobacteria are known from numerous freshwater and marine locations worldwide, and their ecology, distribution, and taxonomy have been documented numerous times. An intense, seasonally occurring water-bloom of the traditional filamentous genus Lyngbya C. Agardh ex Gomont (cf. KomÁreK \& ANAGNOSTIDIs 2005) has appeared annually since 2008 in the large, tropical, volcanic Lake Atitlán, located in the highlands of Guatemala. This is the first case of a typical water-bloom produced by a Lyngbya-like organism from tropical reservoirs. Apparently, the water-blooms have been caused by increasing input of nutrients, particularly phosphorus, into the lake (REJMÁnKová et al. 2011; comp. also Mions et al. 2011-2012).

The traditional genus Lyngbya, based on the type species $L$. confervoides, is characterized by relatively wide filaments $(8-35 \mu \mathrm{m})$ composed of cylindrical and uniseriate trichomes with short cells (usually several times shorter than wide), and firm, relatively narrow gelatinous and colorless or (rarely) yellowish sheaths. The heterocytes, akinetes and branching of any type are lacking. Only four freshwater aerotopate planktic morphospecies are known in Lyngbya, which differ in morphology (mainly in dimensions) and phytogeography. Their main vegetation phase 
exists in plankton in lakes (KoMÁreK 2003; KomÁreK \& Anagnostidis 2005). Unlike other Lyngbya species, they contain reversible gasvesicles in cells concentrated in bundles termed aerotopes. The aerotopes can be irregularly distributed within the cells, or they may develop in segments of the filaments. The species forming the water-blooms in Lake Atitlán corresponded morphologically to Lyngbya robusta.

The phylogenetic relations and the taxonomic position of the planktic Lyngbya species have been studied using molecular analyses to now only of the Mongolian populations of L. hieronymusii (SUDA et al. 1998). More information is known about non planktic members of the genus Lyngbya, which can occur in mass developments in benthic habitats, e.g., the marine L. majuscula (AlBERT et al. 2005) and the freshwater $L$. wollei sensu American authors (e.g., Bridgeman \& Penamon 2010) and their phylogenetic relationships were partly clarified by ENGENE et al. (2012). We transferred Lyngbya robusta from Atitlán into a monospecific culture and, according to our results (based on 16S rRNA gene sequences), all planktic and aerotopated Lyngbya species must be classified as a new genus Limnoraphis.

\section{Material and Methods}

Site description. Lake Atitlán is a volcanic crater lake located in the highlands of southwestern Guatemala, Central America (Figs S1-3), and more than 50\% of the watershed consists of steep slopes. A detailed hydrological and hydrobiological description of the lake are found in REJMÁNKOvÁ et al. (2011); (cf. Table $\mathrm{S} 1$ ). The streams around the lake are easily erodible because the original forests have been replaced with agricultural crops and urban areas in many places. Erosion, combined with uncontrolled wastewater input, has caused increasing eutrophication over the last several decades (Dix et al. 2003). The lake has been recently changed mainly as a consequence of the increase of the $\mathrm{P}$ concentrations from oligotrophic to mesotrophic state. The first water-blooms occurred in 2008 and a major bloom followed in 2009 (Figs 1, 2). The water-blooms had a distinct seasonality. They usually followed the rainy season, which was characterized by the mean air temperature of $18^{\circ} \mathrm{C}$. The temperature of water in epilimnion was relatively uniform during the development of Lyngbya waterblooms and ranged mostly from 19.5 to $22{ }^{\circ} \mathrm{C}$. In the 2008/2009 season, the water-bloom occurred in December and a part of January, in 2009/2010 it lasted from October to December. In 2010 the massive development of Lyngbya increased in August following tropical storm Agatha, but then slowed down and did not form full macroscopic water-blooms. In 2011, a high density of Lyngbya was recorded in March and lasted to May. At other times, the hormogonia of Lyngbya occurred sporadically and irregularly in epilimnion and in sediments near the shores of the wind exposed parts of the lake or in shallow bays.

Material. Field samples were collected from Lake Atitlán from 2008 to 2011 and partly preserved. The living filaments were transferred onto agar plates and isolated in solid BG11 Medium. Isolated strains (reference strain = CCALA 966) were then grown in BG 11 Medium at a temperature of $22{ }^{\circ} \mathrm{C}$ and a light intensity of $70 \mu \mathrm{mol} . \mathrm{m}^{-2} . \mathrm{s}^{-1}$ (16:8 L:D cycle).

In this study three strains were evaluated: Lyngbya robusta CCALA 966 (isolated from Lake Atitlán in 2009), and other related planktic species Planktothrix cryptovaginata "KUTNAR 3" (isolated from the Czech Republic) and Lyngbya hieronymusii $\mathrm{N}-929$ (isolated from Mongolia). First two are deposited in the strain collection of the Institute of Hydrobiology of the Biology Centre of AS CR in České Budějovice, the last strain is deposited in NIES collection, Tsukuba, Japan.

Ultrastructure. For transmission electron microscopy, filaments of Lyngbya robusta were collected from agar cultures from natural material and fixed in two ways:

(a) for three hours using $1 \%(\mathrm{w} / \mathrm{v})$ osmium tetroxide in $0.7 \%(\mathrm{w} / \mathrm{v})$ veronal-acetate buffer $(\mathrm{pH} 6.5)$ with traces of natrium chloride and calcium chloride; (b) for four hours using 3\% (w/v) glutaraldehyde in 66 $\mathrm{mM}$ citrate-phosphate buffer $(\mathrm{pH} 7.3)$, applied at $4{ }^{\circ} \mathrm{C}$, followed by post-fixation with $1 \%(\mathrm{w} / \mathrm{v})$ osmium tetroxide for 1 hour. Fixed material was washed three times (10 min each) with the fixation buffer, instilled into $2 \%(\mathrm{w} / \mathrm{v})$ agar and dehydrated with an ethanol gradient with concentrations increasing from $70 \%$ (50 $\mathrm{min})$ to $100 \%(\mathrm{w} / \mathrm{v})(30 \mathrm{~min})$ followed with absolute acetone. Material was infiltrated with Durcupan ACN Fluka Nr. 1 (Buchs, Switzerland) resin in absolute acetone at room temperature overnight. Thereafter, the acetone concentration was gradually lowered at room temperature over four days, heated to $50{ }^{\circ} \mathrm{C}$ for 4 hours and kept in fresh Durcupan Nr. 2 at $50{ }^{\circ} \mathrm{C}$ for 2 hours. The resin was polymerized in the Beems flat embedding mould by increasing temperatures from $60{ }^{\circ} \mathrm{C}$ to $80^{\circ} \mathrm{C}$, one day each. Sections were cut using a Reichert-Jung ultramicrotome Ultracut E. Ready placed upon supporting grids, and stained with $2.5 \%$ (w/v) uranyl acetate and alkaline Reynolds solution $(3 \%, w / v$, lead nitrate with $3 \%, w / v$, natrium citrate). Sections were examined on FEI Morgagni 268D transmission electron microscope (FEI Inc., Hillsboro, Oregon USA) and photographed with a digital camera. 

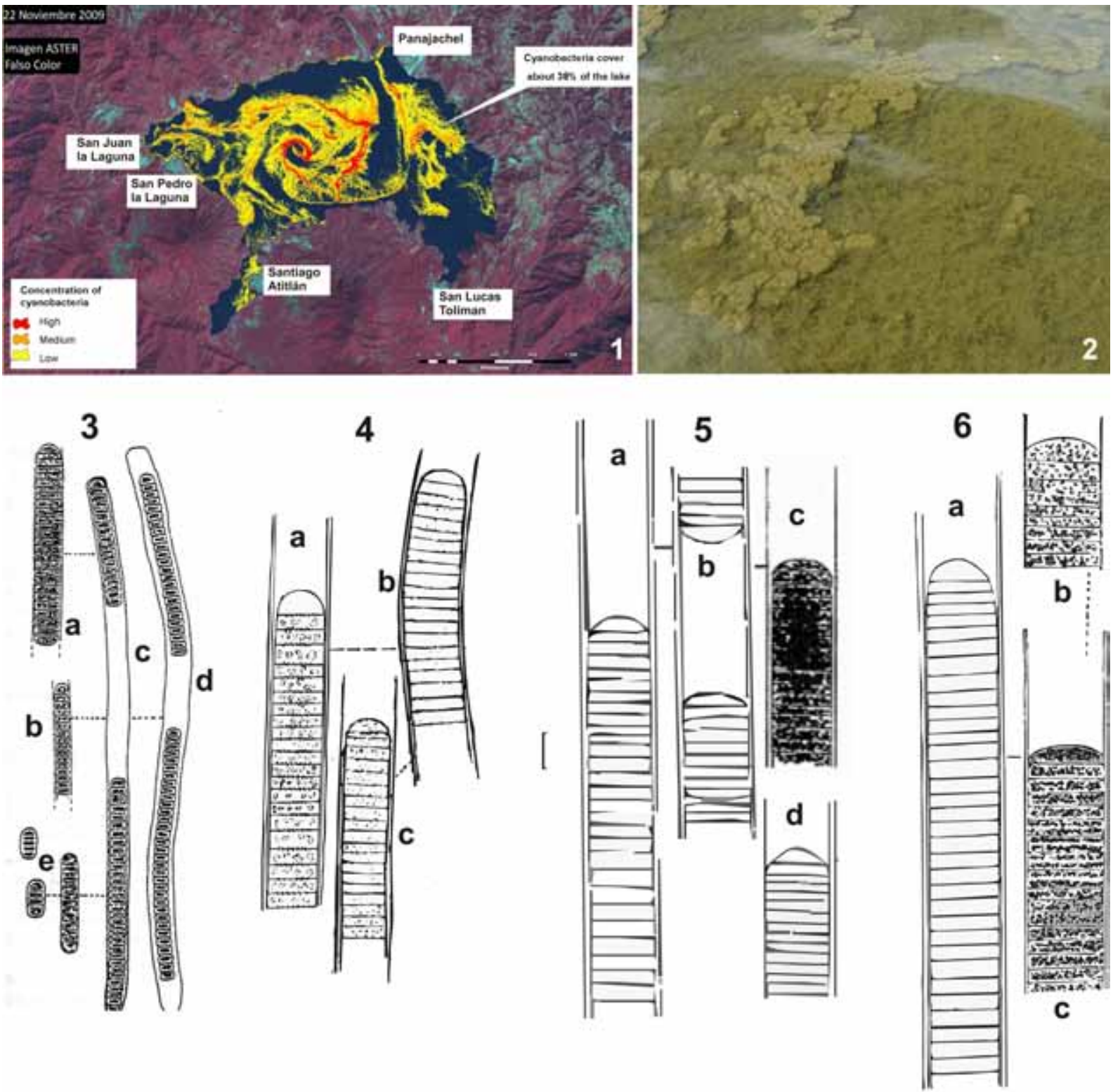

\section{F: $7-9.2 \mu \mathrm{m}$ \\ $\mathrm{T}: \quad 4-9 \mu \mathrm{m}$}

12-16 $\mu \mathrm{m}$

19-20 $\mu \mathrm{m}$

20-24 $\mu \mathrm{m}$

$11-14 \mu \mathrm{m}$

Fig. 1. ASTER satellite image of the cyanobacterial bloom in Lake Atitlán, Guatemala, November 22, 2009 (modified from the CATHALAC information material).

Fig. 2. Dense water-bloom of Lyngbya robusta in Lake Atitlán, November 2009 (photo ReJMÁNKová).

Figs 3-6. Morphology of planktic Lyngbya (=Limnoraphis) species with gas vesicles within cells and with dimensions (widths) of filaments (F) and trichomes (T): (3) L. cryptovaginata after ŠKORBATOv in STARMACH 1966; (4) L. hieronymusii after PRESCOTT 1962 and Lemmermann 1905; (5) L.robusta after KomÁrek \& KomárkovÁ-Legnerová 2007; (6) L. birgei after Prescott 1962 and G.M. Sмітн 1920.

Pigment analyses. For carotenoid analyses, cells of L. robusta (strain CCALA 966) were removed from liquid culture medium by centrifugation for $10 \mathrm{~min}$ at $4.500 \times \mathrm{g}$. Cells were extracted twice for $15 \mathrm{~min}$ at room temperature using $100 \%$ acetone. Extracts were clarified using $0.2 \mu \mathrm{m}$ nylon filters (Micro-spin centrifuge filter, Alltech, Deerfield, IL, USA) and analyzed by high performance liquid chromatography (HPLC) using the Agilent 1100 Series system (Agilent
Technologies Inc., Palo Alto, California, USA) equipped with the UV-VIS diode-array detector (Agilent DAD 61315B). Pigments were separated using a modified method of VAN HEUKELEM \& THOMAS (2001) on a $35^{\circ} \mathrm{C}$ Phenomenex Luna $3 \mu \mathrm{C} 8(2) 100 \AA$ column with binary solvent system (0 min 100\% A, 20 $\min 100 \%$ B, $25 \min 100 \%$ B, $27 \min 100 \%$ A, 301 min $100 \%$ A; A: $70 \%$ methanol $+28 \mathrm{mM}$ ammonium acetate, $\mathrm{B}$ : methanol). The peak assignment was based 

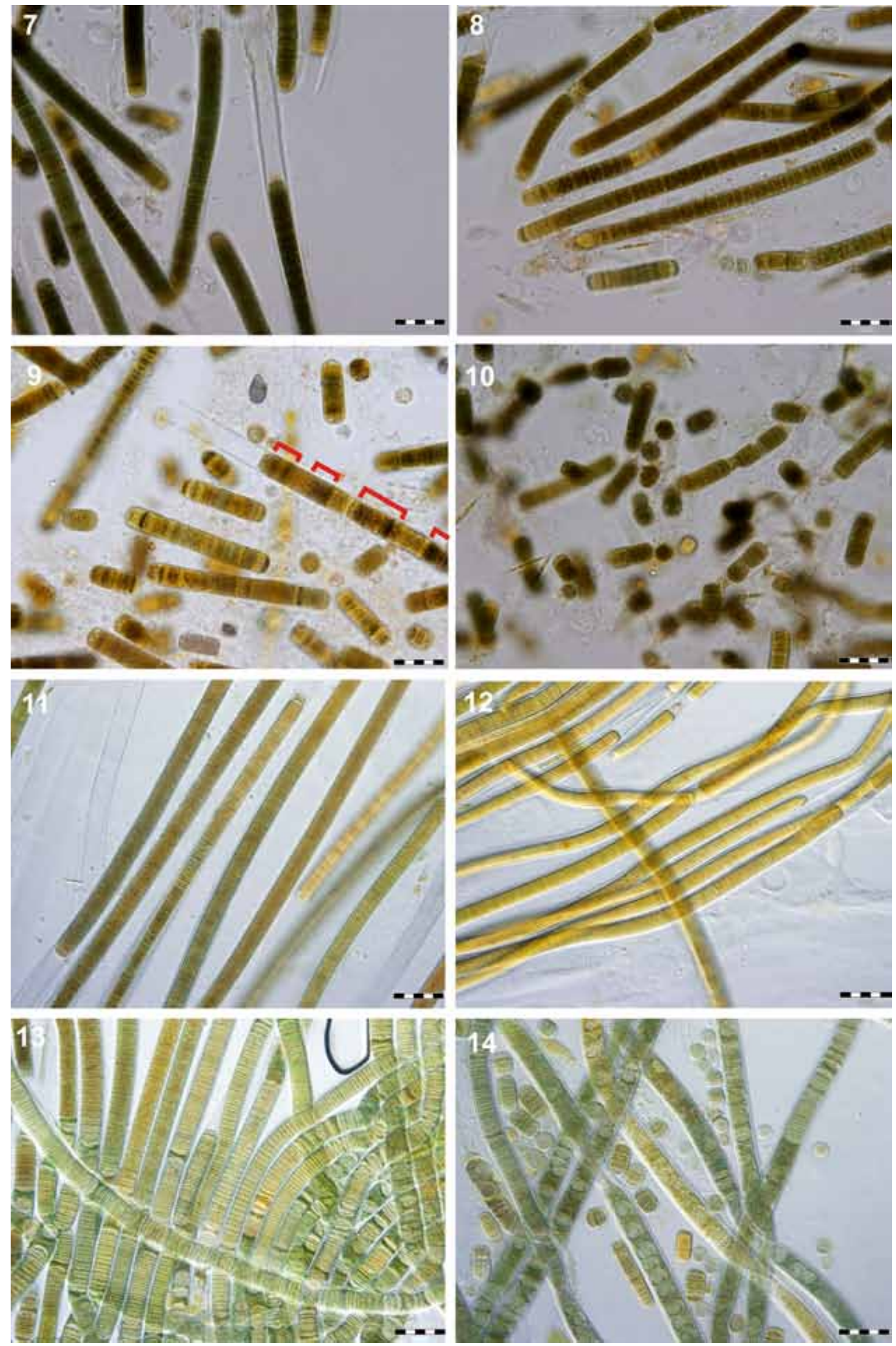
on obtained absorption spectra and retention behavior. For phycobilin analysis, pelleted cells were either stored at $-80{ }^{\circ} \mathrm{C}$ or immediately resuspended to the same final volume in $10 \mathrm{mM}$ phosphate buffer $(\mathrm{pH}$ 6.8). Pellets were subjected to freeze-thaw cycles, i.e. immersed in $5 \mathrm{ml}$ of $10 \mathrm{mM}$ phosphate buffer ( $\mathrm{pH}$ 6.8) and frozen at $-20{ }^{\circ} \mathrm{C}$, thawed, and extracted at $5{ }^{\circ} \mathrm{C}$ for $24 \mathrm{~h}$. This freeze-thaw cycle was repeated three times. All supernatants were pooled, centrifuged at $12,000 \mathrm{rpm}$ for $15 \mathrm{~min}$ at $4{ }^{\circ} \mathrm{C}$, and the blue supernatant was analyzed. Spectrophotometric quantification was measured from 400 to $750 \mathrm{~nm}$ in a UV-VIS 3000 Shimadzu dual wavelength dual beam spectrophotometer using a $1 \mathrm{~cm}$ quartz glass cuvette against a phosphate buffer blank. Absorbance values were scatter-corrected by subtracting the absorbance at $750 \mathrm{~nm}$ from the absorbance maximum of the phycobilin peak [565 nm for phycoerythrin (PE); 620 $\mathrm{nm}$ for phycocyanin (PC); $650 \mathrm{~nm}$ for allophycocyanin (AC)]. The amounts of PE, PC, and AP were calculated by using the simultaneous equations of BENNETT \& BOGORAD (1973) and the extinction coefficients from BRYANT et al. (1979).

Toxicity. DNA was extracted from $100 \mathrm{mg}$ of dried water-bloom material using the MP Biosystems Soil DNA Extraction kit according to manufacturers specifications. To test DNA quality, extractions were pre-screened using 16S rRNA gene PCRs from two duplicate DNA extractions using the cyanobacterialspecific primers $27 \mathrm{~F} 1$ and $809 \mathrm{R}$ (JungBLuT et al. 2005). Toxins were assessed individually, for each toxin, using the primer pairs DQmcyF/DQmcyR for microcystin/nodularin; sxtA-F/sxtA-R for saxitoxin; and cyrF/cyrR for cylindrospermopsin (AL-TEBRINEH et al. 2001). As controls, mcyE positive Microcystis sp. PCC 7806, sxtA positive Cylindrospermopsis raciborskii $\mathrm{T} 3$ and cyrA positive Cylindrospermopsis raciborskii AWT205, were used. When primers amplified the positive control but not the sample DNA, $1 \mathrm{ng}$ of positive control DNA was used to spike the sample to ensure no PCR inhibitors were present. PCR was performed using $0.2 \mathrm{U}$ of Taq DNA polymerase (Bioline, A Meridian Life Science ${ }^{\circledR}$ Company, UK) in a $20 \mu \mathrm{l}$ reaction mix containing $2.5 \mathrm{mM} \mathrm{MgCl}_{2}$,
PCR buffer (Bioline), $0.2 \mathrm{mM}$ dNTPs (Bioline), $10 \mathrm{pmol}$ (or $25 \mathrm{pmol}$ for DQmcyF/DQmcyR) of each primer (Sigma-Genosys, Sigma ${ }^{\circledR}$ Life Science Custom Products, Canada) and $1 \mathrm{ng}$ of template DNA. Thermal cycling was performed in a Mastercycler ${ }^{\circledR}$ (Eppendorf, Germany). PCR conditions for 16S rRNA gene amplification were performed as previously described (JungBLUT et al. 2005). PCR conditions for toxin-specific primer pairs were: initial denaturation step of four min at $94{ }^{\circ} \mathrm{C}$ was followed by 45 cycles involving a $10 \mathrm{~s}$ denaturation step at $94{ }^{\circ} \mathrm{C}$, a $20 \mathrm{~s}$ annealing step at $60{ }^{\circ} \mathrm{C}$ and a $25 \mathrm{~s}$ elongation step at $72{ }^{\circ} \mathrm{C}$, followed by a final extension step of $5 \mathrm{~min}$ at $72{ }^{\circ} \mathrm{C}$. The amplicons were electrophoresed through a $1 \%$ agarose gel, stained with $0.5 \mu \mathrm{g} . \mathrm{ml}^{-1}$ ethidium bromide and photographed with a Gel Doc XR camera using Quantity one 4.6.1 software (Bio-Rad, Bio-Rad Laboratories, Inc. Berkeley, California, USA).

DNA extraction, PCR, 16S rDNA sequencing. The biomass for the phylogenetic analyses was harvested in the exponential growth phase by repeated centrifugation, during which the filaments were washed several times with a $\mathrm{NaCl}$ aqueous solution of concentration $1 \mathrm{~g} . \mathrm{l}^{-1}$ to remove or reduce mucilaginous substances. The final biomass pellets were stored at $-20{ }^{\circ} \mathrm{C}$. For the $16 \mathrm{~S}$ rRNA gene sequencing, DNA was extracted using UltraClean ${ }^{\mathrm{TM}}$ Microbial DNA Isolation Kit (MO BIO Laboratories, Inc., Carlsbad, California, USA). The 16S rRNA gene and ITS region were amplified with primers 16S27F, 23S30R (TATON et al. 2003) and CYA359F (NüBEL et al. 1997). The amplification was carried out as follows: one cycle of $5 \mathrm{~min}$ at $94{ }^{\circ} \mathrm{C} ; 10$ cycles of $45 \mathrm{~s}$ at $94{ }^{\circ} \mathrm{C}, 45 \mathrm{~s}$ at $57{ }^{\circ} \mathrm{C}$, and $2 \mathrm{~min}$ at $72^{\circ} \mathrm{C}$; 25 cycles of $45 \mathrm{~s}$ at $94{ }^{\circ} \mathrm{C}$, $45 \mathrm{~s}$ at $54{ }^{\circ} \mathrm{C}$, and $2 \mathrm{~min}$ at $72{ }^{\circ} \mathrm{C}$; the final elongation step was $7 \mathrm{~min}$ at $72{ }^{\circ} \mathrm{C}$. PCR products were cleaned using NucleoSpin ExtractII kit (Macherey-Nagel $\mathrm{GmbH} \&$ Co. KG, Düren, Germany). PCR products were then used as templates for sequencing with primers 16S27F, 23S30R (TATON et al. 2003), primer cAlaR (WILmotte et al. 1994), primers WAW1486R and Primer 14 (WILmotte et al. 1993), and primer CYA781F (a) and CYA359F (NüBEL et al. 1997). The sequencing was performed at a commercial facility

Figs 7-10. Trichome morphology of Limnoraphis robusta changes in natural population from Lake Atitlán: (7) young filaments developing from hormogonia, intensely growing with common aerotopes in cells; (8) vegetative filaments from starting vegetation of water bloom; (9) start of the disintegration of trichomes in hormogonia at the end of the vegetation period, in the apical part of one filament are marked segments with common aerotopes in cells; (10) disintegration of filaments in short hormogonia. Scale bars $50 \mu \mathrm{m}$.

Figs 11-14. Trichomes of Limnoraphis robusta from culture CCALA 966. Successive stages during the development of the Limnoraphis population in culture and the disappearing of gas vesicles (disappearing of "black segments" in trichomes) is well visible. Sheaths and aerotopes in cells are slightly reduced in the material from cultures: (11) filaments from the strain CCALA 966 after reinoculation, in young trichomes are parts with developed aerotopes (blackish segments); (12-13) aerotopes disappear during longer cultivation on agar plates (12) as well as in liquid medium (13); (14) disintegration of trichomes in short hormogonia and monocytes. Scale bars $50 \mu \mathrm{m}$. 
(Laboratory of Genomics, Biology Centre of AS CR, České Budějovice, Czech Republic).

Phylogenetic analyses. Partial 16S rRNA sequences (1211 bp) were aligned using BioEdit version 7.0.9.0 (HALL 1999) and this alignment was then edited manually. Phylogenetic trees were constructed using maximum likelyhood (ML) and neighbour-joining (NJ) (SAitou \& Nei 1987) algorithms in the program PAUP* version 4.0b10 (SwOFFord 2003). For ML, the $\mathrm{GTR}+\mathrm{I}+\mathrm{G}$ evolutionary model of substitution was found for the best fit to the data using ModelTest 3.7 (Posada 2008). The parameters (base frequencies, rate matrix of substitution types and shape of gamma distribution) were estimated from the data. One hundred and 1,000 bootstrap replicates were performed for ML and NJ analysis, respectively. Nucleotide sequences of studied planktic strains were deposited at GenBank under the accession numbers JN854138-JN854140.

Taxonomic evaluation. The separated phylogenetic position of Lyngbya robusta and four related strains of other planktic "Lyngbya" species (L. hieronymusii, $L$. cryptovaginata), following from the 16S rRNA gene sequencing was accepted as the basis of their taxonomic classification. They belong morphologically to the traditional family Oscillatoriaceae, genus Lyngbya sensu lato (ANAgnostidis \& KomÁrek 1988; KomÁreK \& ANAGNOSTIDIS 2005). For the final identification, all available criteria for polyphasic evaluation were used. Their phylogenetic, morphological and ecological position is isolated in such a degree, that the genus Limnoraphis was validly established from this cluster on the basis of Botanical nomenclatoric rules (ICBN; MCNeILl et al. 2006). The isolated strain of Lyngbya (=Limnoraphis) robusta was deposited in the collections CCALA (Třeboň) and PCC (Paris). The exsiccated type material is deposited in the herbaria of Moravian Museum in Brno, Czech Republic, under the number BRNM-HY 2365.

\section{Results}

Lyngbya robusta (= Limnoraphis robusta comb. nov.) is a novel water-bloom forming cyanobacterium from mesotrophic waters in the Lake Atitlán. As well as other related planktic Lyngbya-species (Figs 3-6), it lives in stagnant water reservoirs in solitary, \pm straight or slightly curved filaments, which make free and irregular clusters only in mass development. They have more or less uniform morphology: trichomes are 15-19 $\mu \mathrm{m}$ wide, straight, composed of short cells, which only occasionally can reach up to semi-quadratic shape. The cells are usually
2-4 times shorter than wide. The common cytomorphological feature of planktic Lyngbya species, which separates them from other Lyngbya species, is the ability to produce gas vesicles in cells (gathered to aerotopes); this character does not occur in any other type of Lyngbya. Gas vesicles and aerotopes are not developed regularly along the whole trichome and their frequency changes during the vegetation period (cf. Figs 7-10 and 11-14). The production of aerotopes was facultative when grown in culture. Trichomes are cylindrical, usually not constricted at crosswalls, never distinctly narrowed towards ends, end cells are widely rounded, without calyptra. The cross-walls can be only exceptionally and slightly constricted. The sheaths are firm, clearly visible, relatively thick (4-12 $\mu \mathrm{m})$, colorless, sometimes more widened, variable and gelatinized in comparison with other Limnoraphis species. They surpass the trichomes in form of a firm tube. Hormogonia vary in length and cell numbers, sometimes reduced to few-celled segments or even monocytes (cf. Figs 10, 14).

Molecular phylogenetic analyses of the 16S rRNA gene showed that the Atitlán planktic and aerotopated strain of Lyngbya (=Limnoraphis) robusta forms a discrete phylogenetic clade with 100\% and 99\% bootstrap supports (Fig. 15, clade A; Table S2) with Limnoraphis hieronymusii comb. nov. from Mongolian lakes (strains N-929, CN4-3) and Limnoraphis cryptovaginata comb. nov. (strain "KUTNAR 3") from an oxbow lake Kutnar, SE Czech Republic. Limnoraphis gen. nov. was a sister clade to B (Fig. 15), identified as "Lyngbya aestuarii" with 96.3\% 16S rRNA gene sequence similarity.

The original planktic Lyngbya species L. robusta, L. birgei, L. hieronymusii and Planktothrix/Lyngbya cryptovaginata must therefore be classified as different species of the same, newly established generic entity (Limnoraphis). These taxa differ from each other morphologically (width of trichomes) and by geographic distribution. The position of planktic Limnoraphis-cluster (Fig. 15, clade A, Table 1) is separated from the typical line of Lyngbya with the marine type-species L. confervoides (Fig. 15 , clade $\mathrm{C}$ ), which occurred in a distinct clade (Fig. 15, clade C). The genus Moorea, recently separated from Lyngbya by ENGENE et al. (2012), formed a second marine clade (Fig. 15, clade D), and freshwater Lyngbya martensiana formed the fifth clade of the original Lyngbya sensu lato (Fig. 
15, clade E). The percent similarity between different Lyngbya clades was calculated (Table 1).

Limnoraphis robusta has a characteristic ultrastructure. Cell walls are thick, distinct, and cross-walls are slightly undulate (Figs 16-22). Walls of necridic cells form typical morphological rests (nc) at the ends of the disintegrated filaments. The sheath is composed of several layers of the same structure (ms). Numerous short thylakoids (th) are situated \pm near walls and cross-walls and agglomerated in very dense, irregular fascicles. Numerous pores penetrating the crosswalls between the cells are clearly visible (Fig. 21). Gas vesicles (gv) are parallel arranged in aerotopes and situated more or less in whole cell volume. Irregularly scattered polyphosphate granules, cyanophycin granules, carboxysomes, lipidic droplets and ribosomes are visible. Some thylakoids can be slightly widened, especially near cross walls, although majority of thylakoids are densely arranged and short.

The filaments of Limnoraphis robusta are brownish colored. The color is well recognizable in natural samples (in massive water-blooms, Fig. 2 ) and particularly in cultures, when gas vesicles are absent (Figs 9, 11-13). Pigment analyses showed the presence of chlorophyll- $a$, the carotenoids myxoxanthophyll, $\beta$-carotene and, in less quantity, canthaxanthin, echinenon and polar xanthophylles (Figs 23, S4). Phycobilins were consistent with other cyanobacteria (Fig. 24). The complex of carotenoids covers evidently other pigments and causes the atypical brown coloration of biomass both in culture and natural water-bloom.

Limnoraphis robusta belongs to oscillatorialean cyanobacteria without heterocytes, which are capable of nitrogen fixation. The fixation proceeds during the night and the nitrogenase activity is enhanced by the addition of phosphorus and iron (REJMÁNKOVÁ et al. 2011 and unpublished data). The presence of firm sheaths and clustering in mats evidently helps to induce favorable conditions for nitrogen fixation, which is intensive particularly during the night. The presence of dinitrogenase reductase gene, nifH has been confirmed (comp. also WoodHouse et al., pers. comm.).

Genomic DNA extracted from Limnoraphis robusta water-bloom did not yield a positive result for any of the toxin gene primer assays. The toxic screening by PCR returned negative results for the 4 major cyanotoxins (SXT, MCY, CYN, NOD).
Duplicate DNA samples positively amplified the 16S rRNA gene and all primer pairs successfully amplified spiked positive control.

Taxonomic solution. The phylogenetic cluster of Limnoraphis (planktic Lyngbya-strains, Fig. 15A) contains two strains of Lyngbya hieronymusii (cf. SuDA et al. 1998 from lakes of Mongolia; strains CN4-3 and N-929), a strain of L. robusta isolated from the Lake Atitlán, Guatemala, and a strain of Planktothrix cryptovaginata, isolated from central Europe (an old oxbow lake Kutnar in SE Czech Republic). The morphology of all these types is similar (cf. Figs 3-6). Planktothrix cryptovaginata (originally described also as Lyngbya) differs from other Planktothrix species by the presence of sheaths and by distinct phylogenetic affiliation. This whole Limnoraphis cluster (originally Lyngbya hieronymusii, Lyngbya robusta, Planktothrix cryptovaginata) should therefore be characterized as a special generic entity, with three species differing morphologically, by ecology and geographic distribution. Lyngbya birgei from North American mesotrophic lakes must be included also to this cluster according to the typical morphology and ecology. The Limnoraphis clade, based upon molecular, morphological and ecological data, is distinct from other clusters of Lyngbya sensu lato.

\section{Limnoraphis gen. nov.}

Filamenta cyanoprocaryotica, simplicia, libera, solitaria, 5-25 $\mu \mathrm{m}$ lata, vel in fasciculis parvis, fatiscentis, aggregata, recta vel paucim flexuosa, vaginata. Vaginae plus minusve firmae, achroae, hyalinae, tenues vel paucim incrassatae. Trichoma uniseriata, ad dissepimenta non constricta vel paucim constricta, cylindrica, ad apices non attenuata, non distincte calyptrata. Cellulae cylindricae, curtae, semper brevior quam latae, cum vesiculis gaseosis (aerotopis) impletae. Heterocyta akinetesque carentes. Reproductio hormogoniis cylindraceis. - Praecipue natantes in plancto aquis dulcis.

\section{Limnoraphis hieronymusii (LeMMERMANN) comb. nov., type species}

(basionym: Lyngbya hieronymusii LEMMERMANN, Forschungsber. biol. Stat. Plön 12: 146, 1905); this taxon was selected as the type species, because it is the oldest and best known species from this cluster, with type material deposited in collection BREM (Bremen, Germany).

Filaments cyanoprokaryotic, simple, solitary, free-floating, 5-25 $\mu \mathrm{m}$ wide, or growing in small 


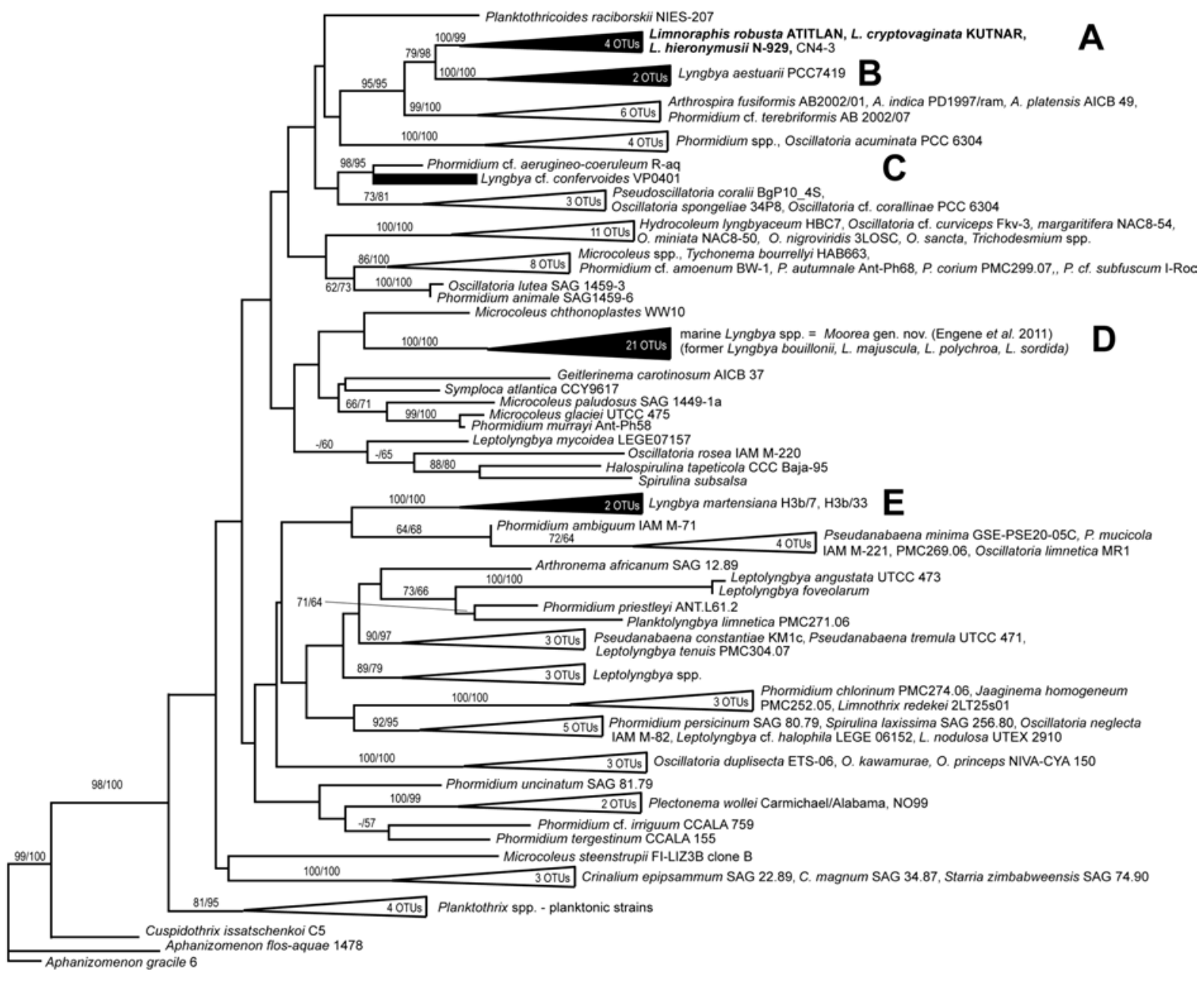

0.1

\section{cluster A:}

Lyngbya robusta ATITLAN 100/99 Lyngbya hieronymusii N-929

Planktothrix cryptovaginata KUTNAR

Lyngbya hieronymusii var. hieronymusii CN4-3

\section{cluster D:}

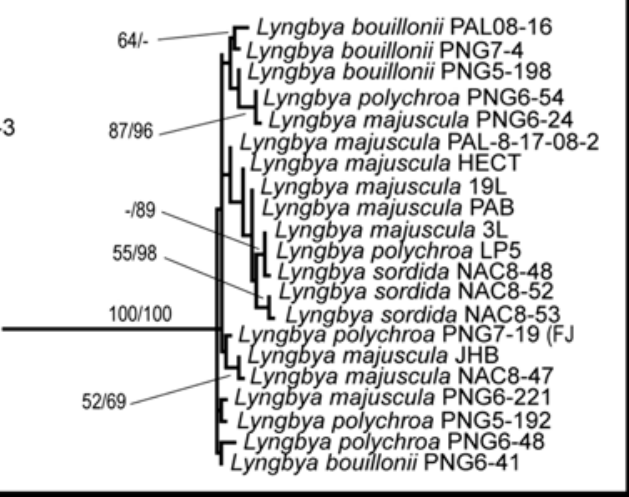

Fig. 15. Maximum Likelihood tree based on the 16S rRNA gene sequences (1211 bp) showing the clustering of strains from the traditional genus Lyngbya. Numbers near nodes indicate bootstrap values of ML/NJ over $50 \%$. Cluster A contains the planktic types with aerotopes in cells, corresponding to Limnoraphis gen. nov. The strains whose 16S rRNA gene sequences were acquired within this study are in bold. Clusters containing cyanobacteria that were originally classified into the genus Lyngbya sensu lato are marked with black colour. Description of clusters B-E see in text. Cluster D is derived from EnGENE et al. 2012. Genbank Accession numbers are in Supplementary Table S2. 
aggregations, straight or slightly curved, with distinct sheaths. Sheaths firm, colorless, hyaline, thin or slightly widened. Trichomes uniseriate, not or slightly constricted at the cross-walls, cylindrical, not narrowed towards ends, without clear calyptra. Cells cylindrical, short, always wider than long, with facultative gas vesicles (and aerotopes), present in distinct segments of a trichome. Heterocytes and akinetes missing. Reproduction by intense hormogonia production. - Mainly free-floating in freshwater plankton.

Limnoraphis birgei (G.M.SмIтн) comb. nov. Basionym: Lyngbya birgei G.M.Sмітн, Bull. Torrey Bot. Club 43(9): 482, 1916.

\section{Limnoraphis cryptovaginata (ک̌KORBATOV) comb.} nov.

Basionym: Lyngbya cryptovaginata ŠкоRватоv, Not. Syst. Inst. Crypt. Horti Petrop. 2(6): 88, 1923.

Synonym: Planktothrix cryptovaginata (ŠкоRвATOv) Anagnostidis et Komárek, Algol. Stud. 50-53: 416, 1988.

\section{Limnoraphis robusta (PARAKUTTY) comb. nov.} Basionym: Lyngbya hieronymusii f. robusta Parakutty, Proc. Ind. Acad. Sci. 11: 123, 1940. Synonym: Lyngbya robusta (ParakUtTY) KomÁreK et KomÁrkovÁ-Legnerová, Hoehnea 34(1): 55, 2007.

Reference strain: CCALA 966. The reference strain is deposited in the collection CCALA at the Institute of Botany of the Academy of Sciences of the Czech Republic.

Type specimen: BRNM HY 2365; Moravian Museum in Brno, Czech Republic.

\section{Discussion}

Based on the presented results from phylogenetic analyses of the 16S rRNA gene sequences, the traditional genus Lyngbya C. AgARDH ex GomonT 1892 has to be divided into at least five genetic clades, which display less than $95 \%$ of the $16 \mathrm{~S}$ rRNA gene sequence similarity one to another and the genus Limnoraphis (with the type $L$. hieronymusii) should be taxonomically defined (Fig. 15, clade A). The only exception are two strains, identified as halophilic Lyngbya aestuarii (strains with accession nos. AB 075989 and AB 039013) (Fig. 15, clade B). The strain PCC 7419 of Lyngbya aestuarii has $96.3 \%$ of sequence similarity to the Limnoraphis cluster (Table 1).
However, the identification of these strains is not yet confirmed and this cluster needs further morphological and molecular studies as a whole. The cytomorphology and ecology of Lyngbya aestuarii is very different from the planktic cluster A, and their taxonomic separation is highly probable.

The next two clusters comprise marine species: The type species of the genus Lyngbya (L. confervoides) has not yet been well identified (Fig. 15, clade C; "cf."). However, only the species (strains) belonging to this phylogenetic clade should be classified as typical Lyngbya species, but the cluster designated by this name is clearly distinguished from Limnoraphis taxonomically and ecologically. It is a marine species, it grows on rocks in the supralitoral zone, and it completely lacks aerotopes.

Another compact marine group (Fig. 15, clade D), comprising mostly the robust strains from tropical seas (mostly from Pacific ocean), was studied in detail by ENGENE et al. (2012) and classified into the specific genus Moorea, with the type M. producens.

The last cluster comprises benthic and periphytic freshwater Lyngbya-strains ("Eulyngbya"). It is represented especially by the morphospecies Lyngbya martensiana (strains $\mathrm{H} 3 \mathrm{~b} / 7, \mathrm{H} 3 \mathrm{~b} / 33$; Fig. 15, clade E). A more or less homogeneous group of strains and species of identical morphological characters from freshwater alkaline marshes in Belize were studied by TuRICCHIA et al. (2009) (Lyngbya minor, Lyngbya cf. martensiana, Lyngbya cf. ocreata, Lyngbya cf. splendens, Lyngbya sp.). The authors recognized a specific cluster (cluster 9 in TURICCHIA et al. 2009) of these species based on their 16S rRNA gene sequences, receiving a high bootstrap support. We have not included these strains in the phylogenetic tree as they are not available in GenBank. Judging by the high morphological similarity with our strains from cluster $\mathrm{E}$ and also by the presence of the strain identified as Lyngbya cf. martensiana (3CC03S04) in the tree by TURICCHIA et al. (2009), we suppose, however, that all these species probably belong to the same phylogenetic clade. Such types correspond morphologically to the traditional Lyngbya species, but the type species $L$. confervoides is marine and belongs to another phylogenetic clade according to the 16S rRNA gene sequences (Fig. 15, clade C). The taxonomic status of this cluster (Fig. 15, clade E) must be resolved in future. 
The genus Limnoraphis has several specific characters. The intracellular structures display an unusual pattern. The gas vesicles are agglomerated as in other planktic cyanobacteria, however, the distribution of aerotopes along the filaments is irregular. This phenomenon often supports an irregularly changing color of the filament with "dark" segments with cells full of aerotopes, which are irregularly distributed along the filament (Figs $5,9,11)$. Similar "dark" segments are found also in L. hieronymusii (fig. 2 in SudA et al. 1998). Gas vesicles are a diagnostic morphological feature for Limnoraphis coinciding with genetic position of this whole cluster; they are closely connected with the ecology. The composition of pigments is also different from the common water-bloom forming cyanobacterial species. The relatively high amount of xanthophylls and $\beta$-carotene, combined with lower amounts of phycobilins causes the unusual yellow-brown coloration of the macroscopic clusters and mats floating on the water level. No tox-genes have been detected in water-blooms of Limnoraphis. The apparent absence of toxic compounds suggests that $L$. robusta does not manipulate the community with toxins.

The four planktic species of Limnoraphis (L. hieronymusii, L. birgei, L. robusta, L. cryptovaginata) are widely separated from Lyng-bya in our molecular phylogenetic analysis, they possess obligatory aerotopes, and they occur only in the plankton and less frequently in metaphyton (L. cryptovaginata) of freshwater reservoirs. The best-known "Lyngbya" species, described from plankton of mesotrophic lakes in northern Germany is L. hieronymusii (LEMMERMANN 1905). This species has not been confirmed during recent decades in Europe, but it sporadically occurs in other locations within the northern temperate zone of Eurasia. Populations and small water-blooms of this species were recently described in detail by SuDA et al. (1998) from the Mongolian Lake Dalai and from lakes in South Korea (LEE \& BAE 2001). Both cited papers contain valuable data on the ecophysiology and biochemistry of this species.

Interestingly, the report about harmful cyanobacteria blooms in Clear Lake and the Sacramento San Joaquin Delta (California) was presented quite recently, prepared by Mion et al. (2011-2012), in which the planktic, aerotopated "Lyngbya sp.", corresponding evidently to Limnoraphis robusta is presented and documented. It would be a second record of this species in water blooms from western America.

Limnoraphis robusta was originally described from eutrophic, large water-bodies in India (originally as Lyngbya hieronymusii var. robusta) and later also recorded sporadically from Africa and Brazil (cf. ParakUtTy 1940; Desikachary 1959; KomÁreK \& KomÁrKovÁLegnerová 2007). Some changes in morphology of Limnoraphis robusta after the transfer into agarized culture media are also remarkable (cf. Figs $7-10$ and 11-14). The gas vesicles are mostly reduced and mucilaginous sheaths are distinctly thinner and less developed in comparison with natural material. It is an example of morphological changes of cyanobacterial taxa after transfer into the culture conditions.

Limnoraphis birgei G. M. SMITH with relatively short, but wide solitary filaments (20-26 $\mu \mathrm{m}$ wide) occurs in plankton of large mesotrophic to oligotrophic lakes in North America (northern USA, Canada) (G.M. Smith 1916, 1920; Prescott 1966; KLING in litt.). The species was recorded several times and seems to be common, but it has not yet been registered as forming dense populations, and data about the ecology are still scarce. The floristic data of this species from other regions are unconfirmed and problematic. This species was transferred in the genus Limnoraphis only according to the cytomorphological and ecological similarity (cf. Fig. 6).

Limnoraphis cryptovaginata is a metaphytic species of oxbows or small lakes with macrophytes and occurs in central and eastern Europe, and central and southern Asia (cf. ANAGNOSTIDIS \& KOMÁREK 1988). It belongs to the same cluster as Limnoraphis robusta according to phylogenetic relations (Fig. 15). It differs from other Limnoraphis species by smaller dimensions (7-9.2 $\mu \mathrm{m}$ wide filaments), facultative presence of sheaths and constrictions at cross-walls. It occurs in metaphyton of smaller water bodies rather than in plankton.

The genus Limnoraphis, particularly the tropical L. robusta, differs from all other waterbloom forming cyanobacterial species from other genera also by specific ecological characteristics. The high production of "Lyngbya robusta" (= Limnoraphis robusta) in Lake Atitlán is the first case of this type of cyanobacterial "waterbloom" in freshwaters worldwide. However, the development of this "Lyngbya" (= Limnoraphis) water-blooms is apparently not a case of phytogeographic separation, or the consequence 


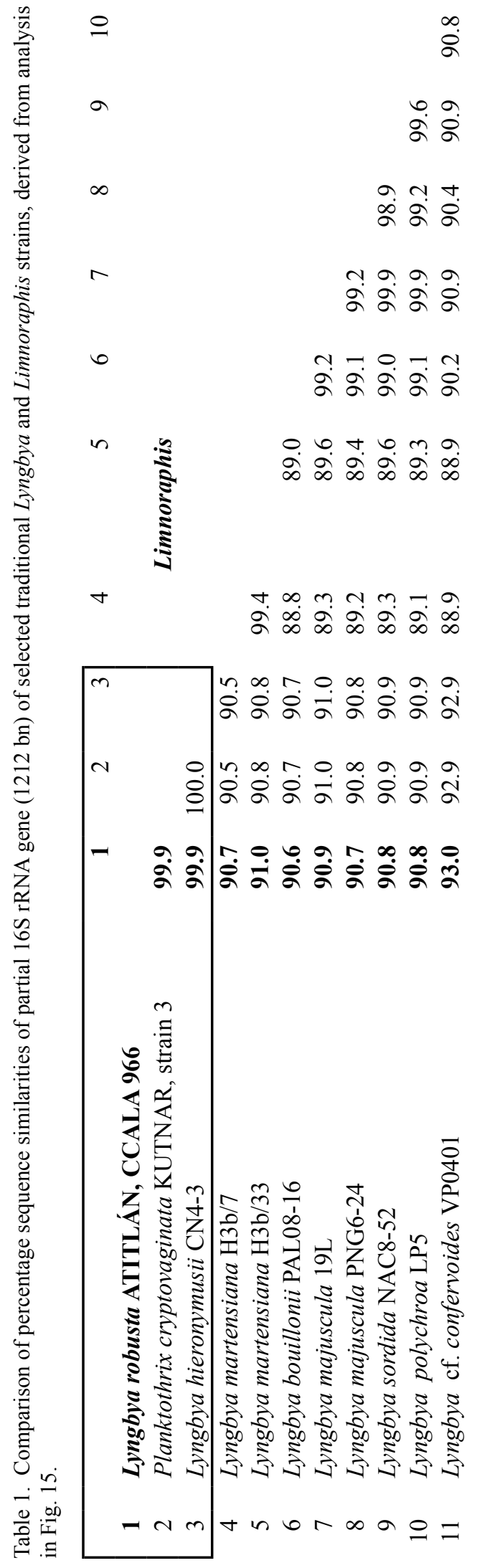

of simple increase of nutrients, because in the same region heavy water-blooms of Microcystis develop in the eutrophic Lake Amatitlán, which is supplied with nitrogen-rich waste waters. According to our results, L. robusta develops here in large, oligoto slightly mesotrophic reservoir with increased content of phosphorus. Concentration of nitrogen in the epilimnion is typically quite low. Therefore, it seems that in the case of Atitlán, Limnoraphis robusta substitutes other species due to specific mesotrophic conditions with remarkable increase of phosphorus. It is also an interesting evidence of the potential development and vitality of any cyanobacteria as dominant microorganisms in various habitats and their quick adaptation to changing ecological conditions. Rare cyanobacterial genotypes can display enhanced vitality and rapid development, then gradually dominate various habitats.

\section{Acknowledgements}

The study was funded by NSF grant 0940796 (E. Rejmánková), Czech grant RVO 67985939 (J. Komárek), project of GA CR no. P504/10/1501 (E. Zapomělová), GA CR 206/06/0306 (J. Komárková), and the Center for Algal Biotechnology - Algatech CZ.1.05/2.1.00/03.0110 (J. Kopecký). We thank Guatemalan colleagues M. Dix (Universidad del Valle Guatemala) and N. Giron (Universidade Rafael Landivar) for help and advice, and we thank the Guatemalan organizations Amigos del Lago and Todos for el Lago for logistic support. Jason Woodhouse and Brett Neilan were supported by The Centre for Cyanobacteria and Astrobiology, University of New South Wales, Sydney, Australia. We also thank Jana Veselá for help with field sampling, Stephanie Castle for linguistic revision, Dana Švehlová for technical help, and Dr. Olga Skácelová for material and a strain of Limnoraphis cryptovaginata.

\section{References}

Albert, S.; O’Neil, J.M.; Udy, J.W.; Ahern, K.S.; O'Sullivan, C.M. \& Dennison, W.C. (2005): Blooms of the cyanobacterium Lyngbya majuscula in coastal Qeensland, Australia: Disparate sites, common factors. - Marine Pollution Bulletin 51: 428-437.

Al-Tebrineh, J.; Mihali, T.K.; Pomati, F. \& Neilan, B.A. (2010): Detection of saxitoxin-producing Cyanobacteria and Anabaena circinalis in environmental water blooms by Quantitative PCR. - Applied and Environmental Microbiology 76: $7836-7842$. 

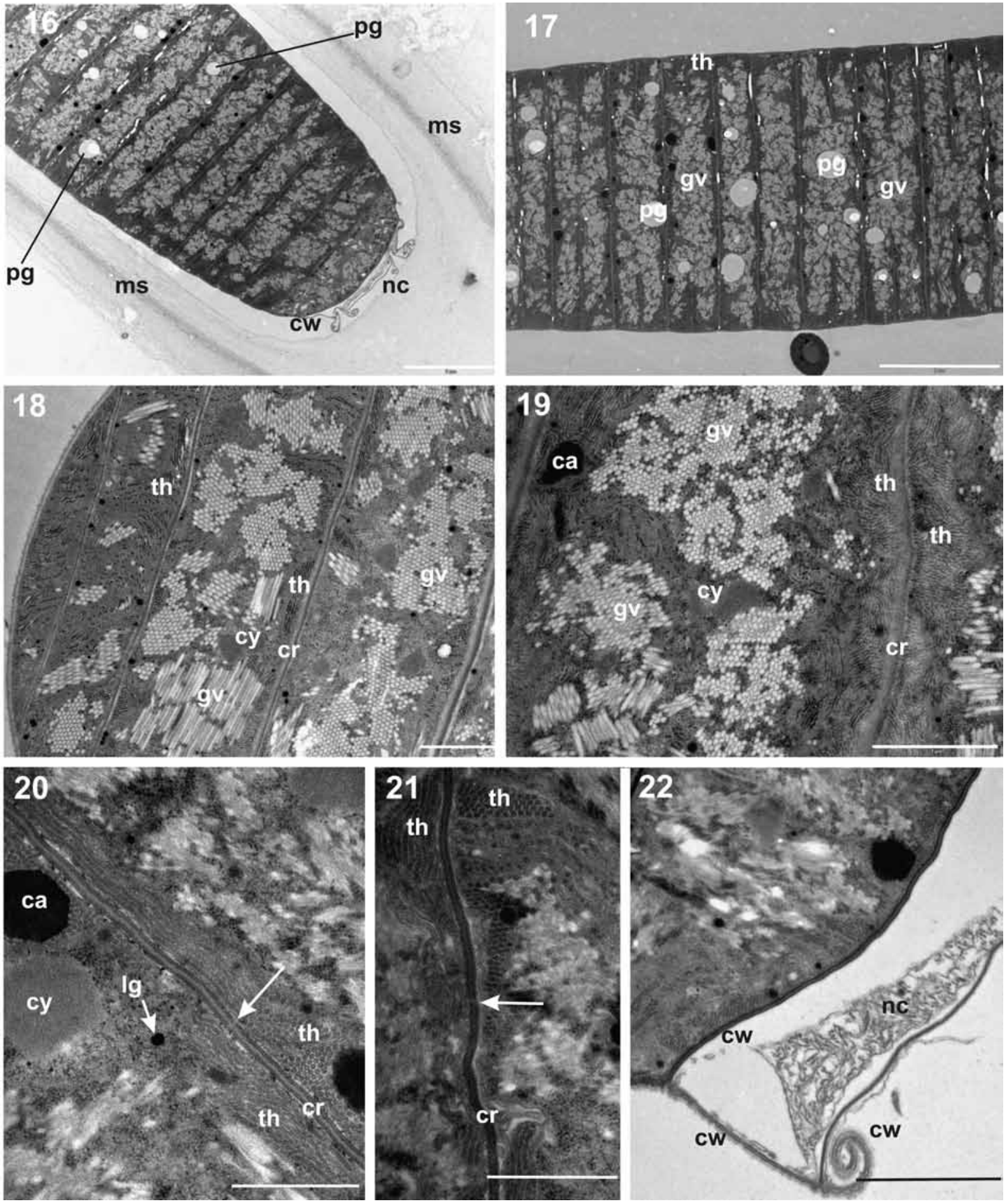

Figs 16-22. Ultrastructural sections of trichomes of Limnoraphis robusta strain CCALA 966 with details of cell walls and cross-walls. In the Fig. 22 are visible typical rests of necridic cells at the ends of disintegrated trichomes [(ca) carboxysomes; (cr) cross-walls; (cw) cell walls; (gv) gas vesicles; (ld) lipidic droplets; (ms) mucilaginous sheath; (pg) polyphosphate granules; (th) thylakoids; (cy) cyanophycin granules; (nc) rests of necridic cells; (white arrows) pores in cross-walls]. Scale bars (16-17) $5 \mu \mathrm{m},(18-19) 1 \mu \mathrm{m},(20-21) 0.5 \mu \mathrm{m},(22) 1 \mu \mathrm{m}$.

Anagnostidis, K. \& KomÁReK, J. (1988): Modern approach to the classification system of cyanophytes 3 - Oscillatoriales. - Algological Studies 50-53: 327-472.

Bennett, A. \& Bogorad, L. (1973): Complementary chromatic adaptation in a filamentous bluegreen alga. - Journal of Cell Biology 58: 419435.

Bryant, D. A.; Guglielmi, G.; Tandeau de Marsac, N.; Castets, A.M. \& Cohen-Bazire, G. (1979): 


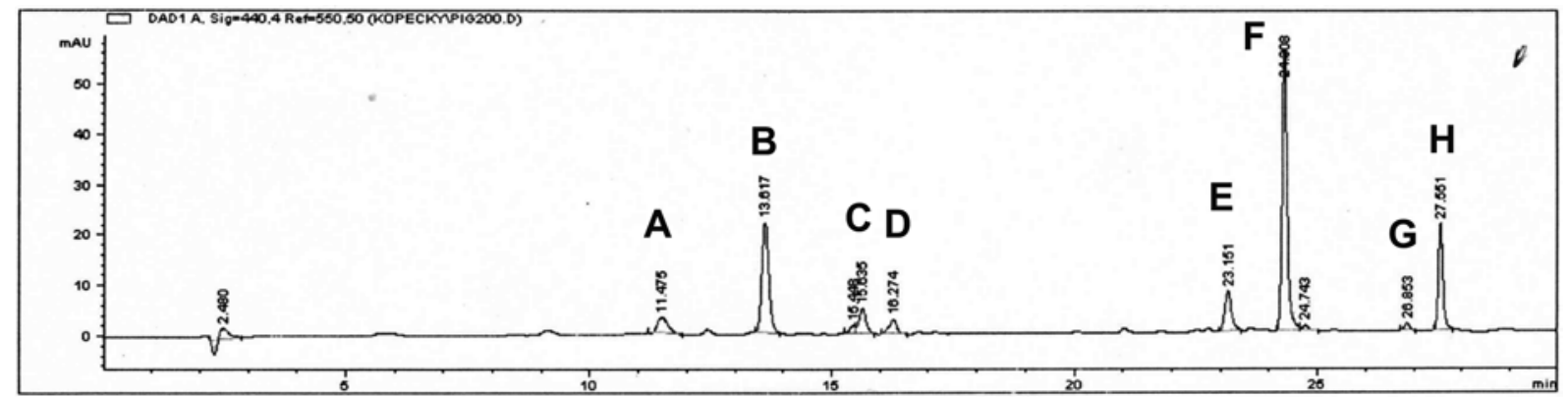

Fig. 23. Spectral analysis of chlorophylls and carotenoids from the strain CCALA 966 [(x) retention time (min.), (y) absorbance at $440 \mathrm{~nm}(\mathrm{nAU})$; in spectrograms A-H: (x) wavelength $(\mathrm{nm}),(\mathrm{y})$ absorbance (mAU); (A) polar xanthophyll I, (B) myxoxanthophyll, (C) polar xanthophyll II, (D) canthaxanthin, (E) echinenon, (F) chlorophylls, (G) cis- $\beta$ caroten, (H) $\beta$ carotene].

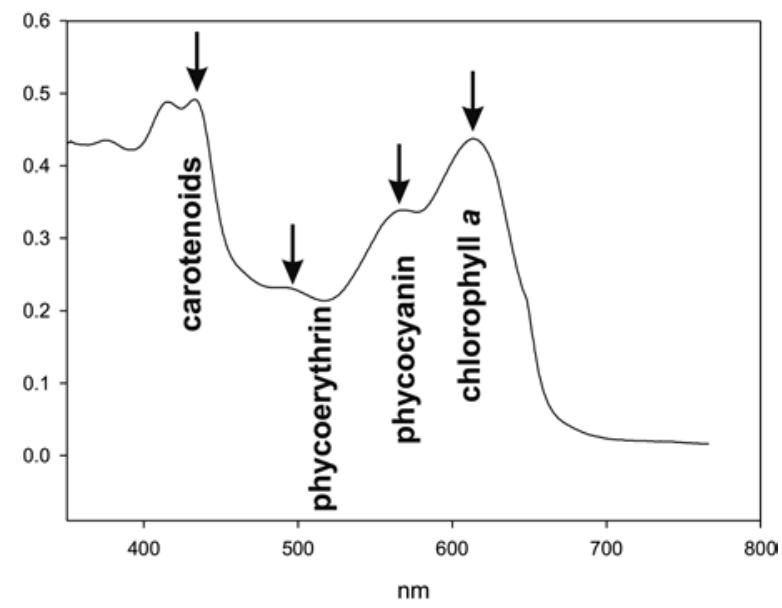

Fig. 24. Spectral analysis of chlorophyll- $a$, phycobilins and carotenoids from the strain CCALA 966 [(x axis) wavelength (nm), (y axis) absorbance (AU)].

The structure of cyanobacterial phycobilisomes: a model. - Archiv für Microbiologie 123:113127.

Bridgeman, T.B. \& Penamon, W.A. (2010): Lyngbya wollei in western Lake Erie. - Journal of Great Lakes Research 36: 167-171.

Castellanos, E. \& Dix, M. (2009): Informe final, UVG Levantamiento de la línea base del Lago de Atitlán Marso de 2009. - Ministerio de Ambiente y Recursos Naturales de Guatemala (report). [In Spanish, not paged.]

Desikachary, T. V. (1959): Cyanophyta. - 686 pp., Academic Press, New York.

Dix, M.; Fortin, I. \& Medinilla, O. (eds.) (2003): Diagnóstico Ecológico-Social y Plan Preliminar de Conservación del Área de Atitlán, TNC, UVG. - 160 pp., Guatemala City. [In Spanish.]

Engene, N.; Rottacker, E.C.; Kaštovský, J.; Byrum, T.; Chol, H.; Ellisman, M.H.; KomÁrek, J. \& Gerwick, W.H. (2012): Moorea producens gen. nov., sp. nov. and Moorea bouillonii comb. nov., tropical marine cyanobacteria rich in bioactive secondary metabolites. - International Journal of Systematic and Ecological Microbiology, DOI: 101099/ijs.0.033761-0.

HaLl, T.A. (1999): BioEdit: a user-friendly biological sequence alignment editor and analysis program for Windows 95/95/NT. - Nucleic Acids Symposium Ser. 41: 95-98.

Jungblut, A.-D.; Hawes, I.; Mountfort, D.; Hitzfeld, B.; Dietrich, D.R.; Burns, B.P. \& Neilan, B.A. (2005): Diversity within cyanobacterial mat communities in variable salinity meltwater ponds of McMurdo Ice Shelf, Antarctica. Environmental Microbiology 7: 519-529.

KomÁReK, J. (2003): Planktic oscillatorialean cyanoprokaryotes (short review according to combined phenotype and molecular aspects). Hydrobiologia 502: 367-382.

KomáreK, J. \& Anagnostidis, K. (2005): Cyanoprokaryota - 2. Teil/ 2nd Part: Oscillatoriales. - In: BÜDEL, B.; KRIENITZ, L.; GÄrtner, G. \& Schagerl, M. (eds): Süsswasserflora von Mitteleuropa 19/2. - 759 pp., Elsevier/Spektrum, Heidelberg.

KomÁreK, J. \& KomÁrkovÁ-LegnerovÁ, J. (2007): Taxonomic evaluation of cyanobacterial microflora from alkaline marshes of northern Belize. 1. Phenotypic diversity of coccoid morphotypes. - Hoehnea 84: 65-111.

LeE, W.J. \& BAE, K.S. (2001): The phylogenetic relationship of several oscillatorian cyanobacteria, forming blooms at Daecheong reservoirs, based on partial $16 \mathrm{~S}$ rRNA gene sequences. - Journal of Microbiology and Biotechnology 11: 504-507.

Lemmermann, E. (1905): Brandenburgische Algen. III. Neue Formen. - Forschungsberichte aus der biologische Station Plön 12: 145-153.

Mioni, C.; Kudela, R.; BAXA, D. \& Sullivan, M. (20112012): Harmful cyanobacteria blooms and their toxins in Clear Lake and the Sacramento - San Joaquin Delta (California). - Report from: Surface Water Ambiente Monitoring Program 
(SWAMP), no. 10-058-150, 84 pp. + Append.

Nübel, U.; Garcia-Pichel, F. \& Muyzer, G. (1997): PCR primers to amplify $16 \mathrm{~S}$ rRNA genes from cyanobacteria. - Applied and Environmental Microbiology 63:3327-3332.

PARAKutTy, P.R. (1940): The Myxophyceae of the Travancore State, India. - Proceedings of the Indian Academy of Sciences B 11: 117-124.

PosADA, D. (2008): ModelTest: phylogenetic model averaging. - Molecular Biology and Evolution 25:1253-1256.

Prescott, G.W. (1962): Algae of the Western Great Lakes Area. - 977 pp., Wm. C. Brown Co. Dubuque, Iowa USA.

Rejmánková, E.; Komárek, J.; Dix, M.; Komárková, J. \& Girón, N. (2011): Cyanobacterial blooms in Lake Atitlán, Guatemala. - Limnologica 41: 296-302.

SAitou, N. \& NeI, M. (1987): The neighbor-joining method: a new method for reconstructing phylogenetic trees. - Molecular Biology and Evolution 4: 406-425.

SkÁcelovÁ, O. \& KomÁReK, J. (1989): Some interesting cyanophyte species from the Kutnar reserve (South Moravia, Czechoslovakia). - Acta Musei Moraviae, Sci. Nat., Brno, 74: 101-116.

Sмiтh, G.M. (1916): A preliminary list of algae found in Wisconsin lakes. - Transactions of Wisconsin Academy of Sciences, Arts and Letters 18: 531565.

Smith, G. M. (1920): Phytoplankton of the Inland Lakes of Wisconsin. I. - Wisconsin Geological and Natural History Survey 57: 1-243.

Suda, S.; Liu, Y.; He, J.; Hu, Z.; Hiroki, M. \& Watanabe, M.M. (1998): Morphological, biochemical and physiological characteristics of Lyngbya hieronymusii var. hieronymusii (Oscillatoriales, Cyanobacteria). - Phycological Research 46 (Suppl.): 51-55.

Swofford, D. L. (2003): PAUP*. Phylogenetic Analysis Using Parsimony (*and other methods). Version 4b10. Sinauer Associates, Sunderland, MA, USA.

Taton, A.; Grubisic, S.; Brambilla, E.; De Wit, R. \& Wilmotte, A. (2003): Cyanobacterial diversity in natural and artificial microbial mats of Lake Fryxell (McMurdo dry valleys, Antarctica): A morphological and molecular approach. Applied and Environmental Microbiology 69: 5157-5169.

Turicchia, S.; Ventura, S.; KomárkovÁ, J. \& KOMÁREK, J. (2009): Taxonomic evaluation of cyanobacterial microflora from alkaline marshes of northern Belize. 2. Diversity of oscillatorialean genera. - Nova Hedwigia 89: 165-200.

Van Heukelem, L. \& Thomas, C.S. (2001): Computer-assisted high-performance liquid chromatography method development with applications to the isolation and analysis of phytoplankton pigments. - Journal of Chromatography A 910: 31-49.

Wilmotte, A.; Neefs, J. M. \& De Wachter, R. (1994): Evolutionary affiliation of the marine nitrogenfixing cyanobacterium Trichodesmium sp. strain NIBB 1067, derived by $16 \mathrm{~S}$ ribosomal RNA sequence analysis. - Microbiology 140: 2159-2164.

Wilmotte, A.; Van der Auwera, G. \& De Wachter, R. (1993): Structure of the 16S ribosomalRNA of the thermophilic cyanobacterium Chlorogloeopsis HTF ('Mastigocladus laminosus HTF') strain PCC7518, and phylogenetic analysis. - FEBS Microbiological Letters 317: 96-100.

Note of authors:

This manuscript was prepared during the year 2011. However, the expedition in Atitlán 2012 found already the homogeneous distribution of Limnoraphis robusta over the whole lake. The development of this cyanobacterium follows evidently after the continual, intense eutrophication of the reservoir. In the year 2012 also other water-bloom cyanobacteria appeared in various locations of the lake, e.g. Microcystis cf. aeruginosa or Aphanizomenon sp.

Supplementary material

the following supplementary material is available for this article:

Table S1. Ecological characteristics of Limnoraphis robusta from the Lake Atitlán, Guatemala.

Table S2. Accession numbers of strains included in the phylogenetic tree.

Fig. S1. Lake Atitlán, Guatemala.

Fig. S2. Geographic location of Lake Atitlán.

Fig. S3. Bathymetric map of Lake Atitlán.

This material is available as part of the online article (http://fottea.czechphycology.cz/contents)

(C) Czech Phycological Society (2013)

Received May 17, 2012

Accepted June 29, 2012 
Table S1. Ecological characteristics of Limnoraphis robusta from the Lake Atitlán, Guatemala. Data on phosphorus (SRP), and nitrogen $\left(\mathrm{NO}_{3}-\mathrm{N}\right)$ are from the central sampling station (DIX and REJMÁNKOVÁ, unpublished data).

\begin{tabular}{|c|c|c|}
\hline \multicolumn{2}{|l|}{ Geographic position } & $\begin{array}{l}91^{\circ} 07^{\prime} 01^{\prime \prime}-91^{\circ} 16^{\prime} 08^{\prime \prime} \text { w.g.l. } \\
14^{\circ} 37^{\prime} 00^{\prime \prime}-14^{\circ} 43^{\prime} 00^{\prime} \text { n.g.w. }\end{array}$ \\
\hline \multicolumn{2}{|l|}{ Altitude above see level } & $1555 \mathrm{~m}$ \\
\hline \multicolumn{2}{|l|}{ Average area of the lake } & $137 \mathrm{~km}^{2}$ \\
\hline \multicolumn{2}{|l|}{ Maximal depth of the lake } & $341 \mathrm{~m}$ \\
\hline \multicolumn{2}{|l|}{ Volume } & $24 \mathrm{~km}^{3}$ \\
\hline \multirow[t]{2}{*}{ SRP, no bloom (April 2010) } & Epilimnion & $5 \mu \mathrm{g} \cdot \mathrm{l}^{-1}$ \\
\hline & Hypolimnion & $25 \mu \mathrm{g} . \mathrm{l}^{-1}$ \\
\hline \multirow[t]{2}{*}{$\mathrm{NO}_{3}-\mathrm{N}$, no bloom (April 2010) } & Epilimnion & $5 \mu \mathrm{g} \cdot \mathrm{l}^{-1}$ \\
\hline & Hypolimnion & $80 \mu \mathrm{g} . \mathrm{l}^{-1}$ \\
\hline \multirow[t]{2}{*}{ SRP, onset of a bloom (June 2010) } & Epilimnion & $20 \mu \mathrm{g} .1^{-1}$ \\
\hline & Hypolimnion & $50 \mu \mathrm{g} .1^{-1}$ \\
\hline \multirow[t]{2}{*}{$\mathrm{NO}_{3}-\mathrm{N}$, onset of a bloom (June 2010) } & Epilimnion & ND \\
\hline & Hypolimnion & $46 \mu \mathrm{g} . \mathrm{l}^{-1}$ \\
\hline
\end{tabular}

Table S2. Accession numbers of strains included in the phylogenetic tree (Fig. 15).

\begin{tabular}{|c|c|c|c|}
\hline Taxon & Strain code & $\begin{array}{l}\text { Genbank } \\
\text { accession } \\
\text { number }\end{array}$ & Note \\
\hline Planktothricoides raciborskii & NIES-207 & АВ045960.1 & \\
\hline Lyngbya robusta & ATITLAN & JN854138 & Limnoraphis robusta comb. nov. \\
\hline Planktothrix cryptovaginata & KUTNAR & JN854139 & Limnoraphis cryptovaginata comb. nov. \\
\hline Lyngbya hieronymusii & N-929, & JN854140 & Limnoraphis hieronymusii comb. nov. \\
\hline Lyngbya hieronymusii & CN4-3 & AB045906.1 & Limnoraphis hieronymusii comb. nov. \\
\hline Lyngbya aestuarii & PCC7419 & AB039013.1 & \\
\hline Lyngbya aestuarii & & AB075989.1 & \\
\hline Arthrospira platensis & AICB 49 & AY672713.1 & \\
\hline Arthrospira fusiformis & $\mathrm{AB} 2002 / 01$ & AY575923.1 & \\
\hline Arthrospira indica & PD1997/ram & AY575931.1 & \\
\hline Arthrospira maxima & $\begin{array}{l}\text { KCTC } \\
\text { AG30054 }\end{array}$ & DQ393281.1 & \\
\hline Arthrospira jenneri & EB 9604 & GQ184185.1 & \\
\hline Phormidium cf. terebriformis & AB 2002/07 & AY575933.1 & \\
\hline Phormidium lumbricale & UTCC 476 & AF218375.1 & \\
\hline Phormidium pseudopriestleyi & ANT.LACV5.3 & AY493600.1 & \\
\hline Phormidium cf. formosum & $\mathrm{P}-\mathrm{O}$ & EU196640.1 & \\
\hline Oscillatoria acuminata & PCC 6304 & AB039014.1 & \\
\hline
\end{tabular}


Table S2 Cont.

\begin{tabular}{|c|c|c|c|}
\hline $\begin{array}{l}\text { Phormidium cf. aerugineo- } \\
\text { coeruleum }\end{array}$ & R-aq & EU196641.1 & \\
\hline Lyngbya cf. confervoides & VP0401 & AY599507.1 & \\
\hline Pseudoscillatoria coralii & BgP10_4S & FJ210722.2 & \\
\hline Oscillatoria spongeliae & $34 \mathrm{P} 8$ & AY615507.1 & \\
\hline Oscillatoria cf. corallinae & PCC 6304 & X84812.1 & \\
\hline Hydrocoleum lyngbyaceum & $\mathrm{HBC} 7$ & EU249124.1 & \\
\hline Oscillatoria sancta & & AB039015.1 & \\
\hline Oscillatoria cf. curviceps & Fkv-3 & EU196623.1 & \\
\hline Oscillatoria nigroviridis & 3LOSC & EU244875.1 & \\
\hline Oscillatoria miniata & NAC8-50 & GU724203.1 & \\
\hline Oscillatoria margaritifera & NAC8-54 & GU724207.1 & \\
\hline Trichodesmium contortum & & AF013028.1 & \\
\hline Trichodesmium tenue & & AF013029.1 & \\
\hline Trichodesmium thiebautii & & AF091321.1 & \\
\hline Trichodesmium hildebrandtii & & AF091322.1 & \\
\hline Trichodesmium havanum & F34-5 & AF518770.1 & \\
\hline Microcoleus antarcticus & UTCC 474 & AF218373.1 & \\
\hline Microcoleus rushforthii & UTCC 296 & AF218377.1 & \\
\hline Microcoleus vaginatus & CSU-U-KK1 & EF667962.1 & \\
\hline Tychonema bourrellyi & HAB663 & FJ184385.1 & \\
\hline Phormidium autumnale & Ant-Ph68 & DQ493874.1 & \\
\hline Phormidium cf. subfuscum & I-Roc & EU196634.1 & \\
\hline Phormidium cf. amoenum & BW-1 & EU196636.1 & \\
\hline Phormidium corium & PMC299.07 & GQ859649.1 & \\
\hline Oscillatoria lutea & SAG 1459-3 & AB115967.1 & \\
\hline Phormidium animale & SAG1459-6 & EF654087.1 & \\
\hline Microcoleus chthonoplastes & WW10 & EF654058.1 & \\
\hline Lyngbya bouillonii & PNG5-198 & FJ041298 & Moorea gen nov. (ENGENE et al. 2012) \\
\hline Lyngbya bouillonii & PNG6-41 & FJ147302 & Moorea gen nov. (ENGENE et al. 2012) \\
\hline Lyngbya bouillonii & PNG7-4 & FJ151519 & Moorea gen nov. (ENGENE et al. 2012) \\
\hline Lyngbya bouillonii & PAL08-16 & GU111927 & Moorea gen nov. (ENGENE et al. 2012) \\
\hline Lyngbya majuscula & $19 \mathrm{~L}$ & AY599501 & Moorea gen nov. (ENGENE et al. 2012) \\
\hline Lyngbya majuscula & PAB & AY599502 & Moorea gen nov. (ENGENE et al. 2012) \\
\hline Lyngbya majuscula & HECT & AY599503 & Moorea gen nov. (ENGENE et al. 2012) \\
\hline Lyngbya majuscula & $3 \mathrm{~L}$ & EU315909 & Moorea gen nov. (ENGENE et al. 2012) \\
\hline Lyngbya majuscula & PNG6-24 & FJ041308 & Moorea gen nov. (ENGENE et al. 2012) \\
\hline Lyngbya majuscula & JHB & FJ151521 & Moorea gen nov. (ENGENE et al. 2012) \\
\hline Lyngbya majuscula & PNG6-221 & FJ356669 & Moorea gen nov. (ENGENE et al. 2012) \\
\hline Lyngbya majuscula & PAL-8-17-08-2 & GQ231522 & Moorea gen nov. (ENGENE et al. 2012) \\
\hline
\end{tabular}


Table S2 Cont.

\begin{tabular}{|c|c|c|c|}
\hline Lyngbya majuscula & NAC8-47 & GU724198 & Moorea gen nov. (ENGENE et al. 2012) \\
\hline Lyngbya polychroa & PNG5-192 & FJ041300 & Moorea gen nov. (ENGENE et al. 2012) \\
\hline Lyngbya polychroa & PNG6-48 & FJ041301 & Moorea gen nov. (ENGENE et al. 2012) \\
\hline Lyngbya polychroa & PNG7-19 & FJ041307 & Moorea gen nov. (ENGENE et al. 2012) \\
\hline Lyngbya polychroa & PNG6-54 & FJ151522 & Moorea gen nov. (ENGENE et al. 2012) \\
\hline Lyngbya polychroa & LP5 & FJ602753 & Moorea gen nov. (ENGENE et al. 2012) \\
\hline Lyngbya sordida & NAC $8-48$ & GU724199 & Moorea gen nov. (ENGENE et al. 2012) \\
\hline Lyngbya sordida & NAC8-53 & GU724206 & Moorea gen nov. (ENGENE et al. 2012) \\
\hline Geitlerinema carotinosum & AICB 37 & AY423710.1 & \\
\hline Symploca atlantica & CCY9617 & GQ402026.1 & \\
\hline Microcoleus paludosus & SAG 1449-1a & EF654090.1 & \\
\hline Microcoleus glaciei & UTCC 475 & AF218374.1 & \\
\hline Phormidium murrayi & Ant-Ph58 & DQ493872.1 & \\
\hline Leptolyngbya mycoidea & LEGE07157 & HQ832916.1 & \\
\hline Oscillatoria rosea & IAM M-220 & $\mathrm{AB} 003164.1$ & \\
\hline Halospirulina tapeticola & CCC Baja-95 & NR_026510.1 & \\
\hline Spirulina subsalsa & & AF329394.1 & \\
\hline Lyngbya martensiana & $\mathrm{H} 3 \mathrm{~b} / 7$ & JN854141 & \\
\hline Lyngbya martensiana & $\mathrm{H} 3 \mathrm{~b} / 33$ & JN854142 & \\
\hline Phormidium ambiguum & IAM M-71 & AB003167.1 & \\
\hline Pseudanabaena mucicola & IAM M-221 & $\mathrm{AB} 003165.1$ & \\
\hline Oscillatoria limnetica & MR1 & AJ007908.1 & \\
\hline Pseudanabaena mucicola & PMC269.06 & GQ859643.1 & \\
\hline Pseudanabaena minima & $\begin{array}{l}\text { GSE-PSE20- } \\
05 \mathrm{C}\end{array}$ & HQ132935.1 & \\
\hline Arthronema africanum & SAG 12.89 & AB115966.1 & \\
\hline Leptolyngbya angustata & UTCC 473 & AF218372.1 & \\
\hline Leptolyngbya foveolarum & & X84808.1 & \\
\hline Phormidium priestleyi & ANT.L61.2 & AY493582.1 & \\
\hline Planktolyngbya limnetica & PMC271.06 & GQ859645.1 & \\
\hline Pseudanabaena constantiae & KM1c & DQ393595.1 & \\
\hline Pseudanabaena tremula & UTCC 471 & AF218371.1 & \\
\hline Leptolyngbya tenuis & PMC304.07 & GQ859652 & \\
\hline Leptolyngbya frigida & ANT.L70.1 & AY493574.1 & \\
\hline Leptolyngbya antarctica & ANT.L18.2 & AY493606.1 & \\
\hline Leptolyngbya laminosa & ETS-08 & FM210757.1 & \\
\hline Phormidium chlorinum & PMC274.06 & GQ859648.1 & \\
\hline Jaaginema homogeneum & PMC252.05 & GQ859646.1 & \\
\hline Limnothrix redekei & $2 \mathrm{LT} 25 \mathrm{~s} 01$ & FM177493.1 & \\
\hline Phormidium persicinum & SAG 80.79 & EF654085.1 & \\
\hline
\end{tabular}


Table S2 Cont.

\begin{tabular}{|c|c|c|c|}
\hline Spirulina laxissima & SAG 256.80 & DQ393278.1 & \\
\hline Oscillatoria neglecta & IAM M-82 & AB003168.1 & \\
\hline Leptolyngbya cf. halophila & LEGE 06152 & HQ832915.1 & \\
\hline Leptolyngbya nodulosa & UTEX 2910 & EF122600.1 & \\
\hline Oscillatoria princeps & NIVA-CYA 150 & AB045961.1 & \\
\hline Oscillatoria kawamurae & & AB298443.1 & \\
\hline Oscillatoria duplisecta & ETS-06 & AM398647.1 & \\
\hline Phormidium uncinatum & SAG 81.79 & EF654086.1 & \\
\hline Plectonema wollei & $\begin{array}{l}\text { Carmichael/ } \\
\text { Alabama }\end{array}$ & EU439567.1 & \\
\hline Plectonema wollei & NO99 & HQ419204.1 & \\
\hline Phormidium cf. irriguum & CCALA 759 & EU196638.1 & \\
\hline Phormidium tergestinum & CCALA 155 & EF654083.1 & \\
\hline Microcoleus steenstrupii & $\begin{array}{l}\text { FI-LIZ3B clone } \\
\text { B }\end{array}$ & EU586740.1 & \\
\hline Crinalium epipsammum & SAG 22.89 & AB115964.1 & \\
\hline Crinalium magnum & SAG 34.87 & AB115965.1 & \\
\hline Starria zimbabweensis & SAG 74.90 & AB115962.1 & \\
\hline Planktothrix rubescens & CCAP 1459/14 & FJ184422.1 & planktic \\
\hline Planktothrix mougeotii & HAB3343 & FJ434250.1 & planktic \\
\hline Planktothrix pseudagardhii & 2LT34S02 & FM177501.1 & planktic \\
\hline Planktothrix agardhii & PMC253.05 & GQ859639.1 & planktic \\
\hline
\end{tabular}



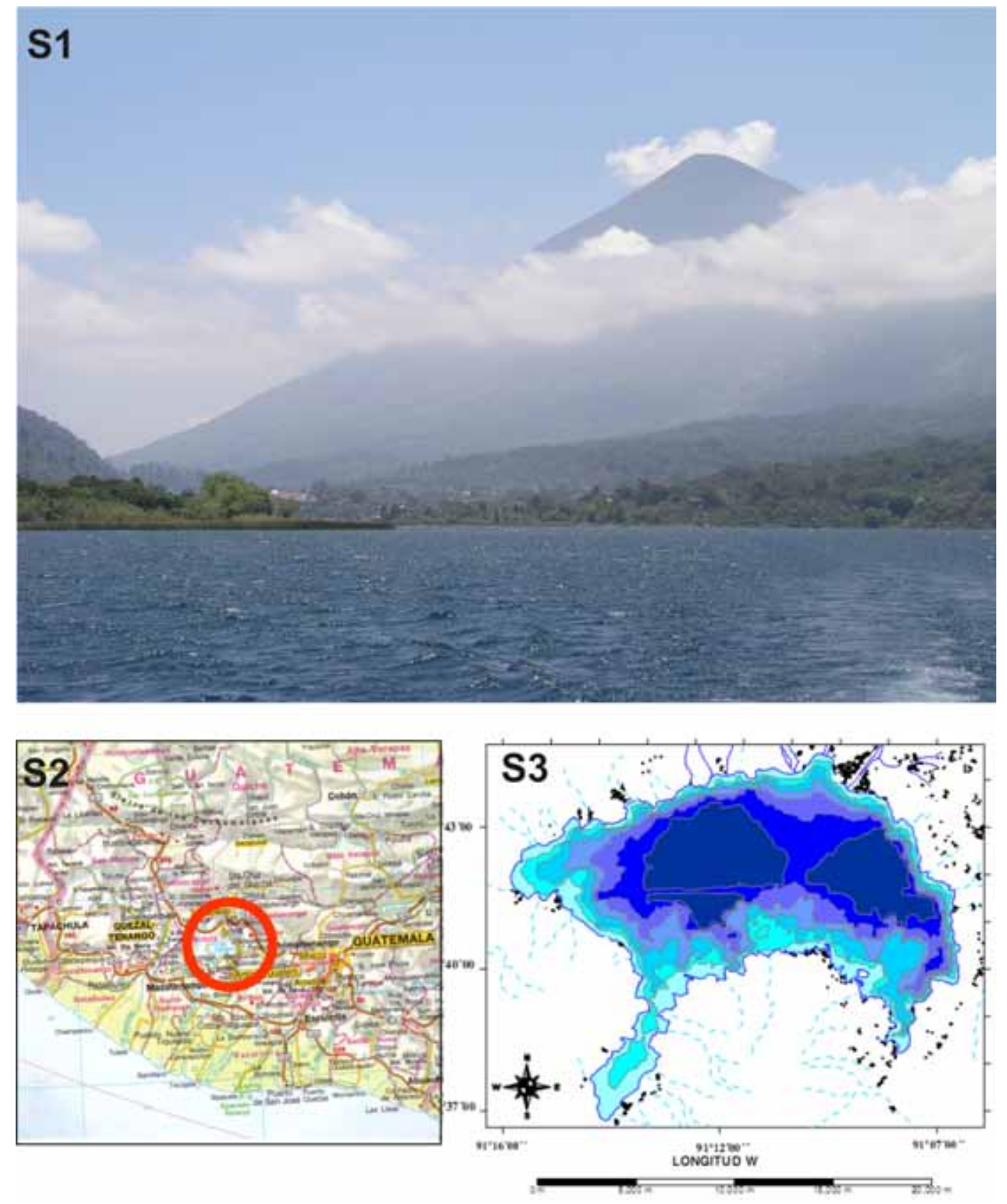

Fig. S1. Lake Atitlán, Guatemala.

Fig. S2. Geographic location of Lake Atitlán.

Fig. S3. Bathymetric map of Lake Atitlán. Blue colors indicate $50 \mathrm{~m}$ depth intervals; maximum depth nearly $350 \mathrm{~m}$; from Castellanos \& Dix 2009. 

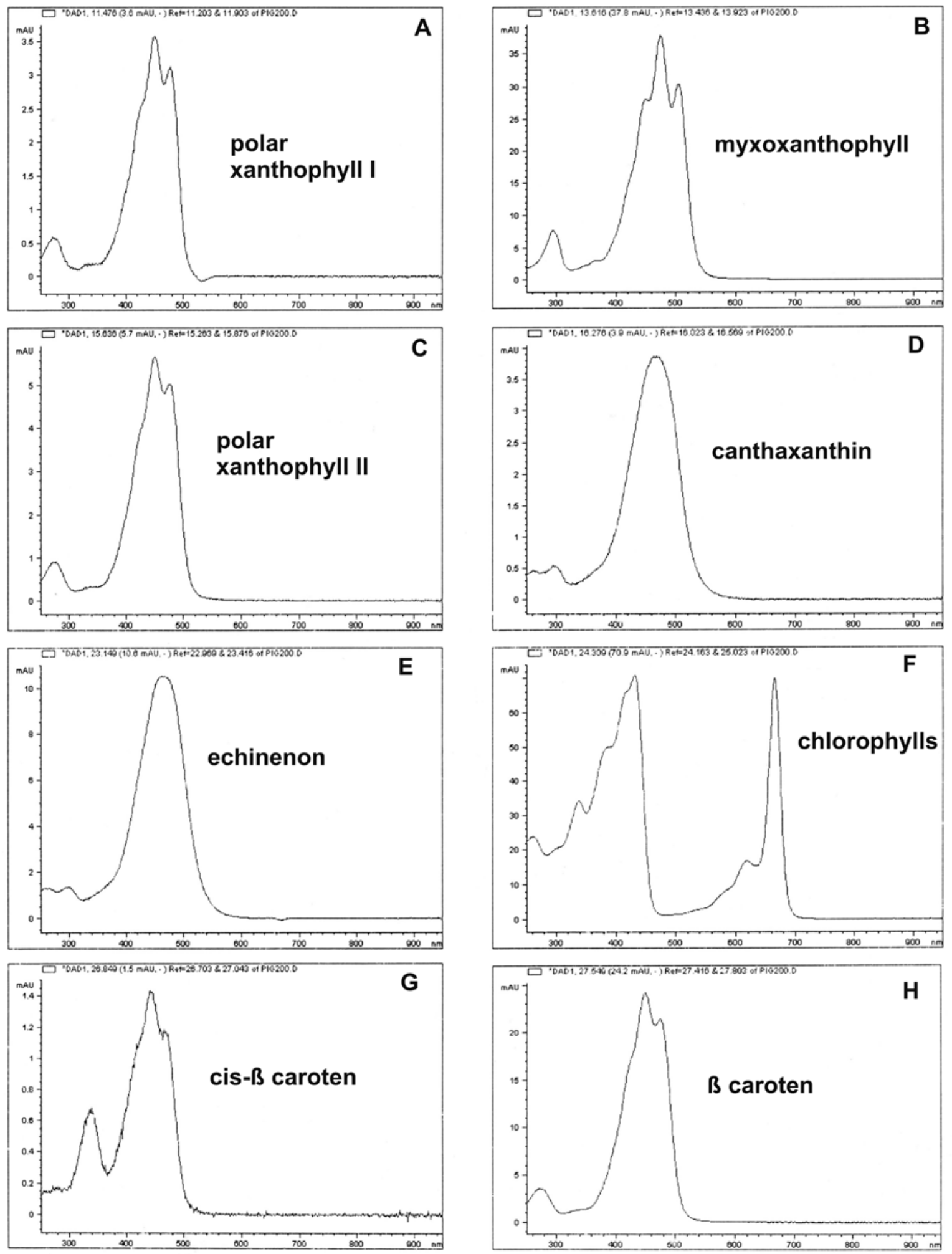

Fig. S4. Spectral analysis of chlorophylls and carotenoids from the strain CCALA 966 [(x) retention time (min.), (y) absorbance at $440 \mathrm{~nm}(\mathrm{nAU})$; in spectrograms A-H: (x) wavelength (nm), (y) absorbance (mAU)]. 